\title{
Sexually transmitted diseases in Italy: clinical returns versus statutory notifications
}

\author{
D Greco, M Giuliani, B Suligoi, M Panatta, A Giannetti ${ }^{\star}$
}

\begin{abstract}
Sexually Transmitted Diseases (STD) surveillance has caught the attention of the Italian public health authorities during the past decades. The spread of HIV infection increased the awareness of the need for a better STD surveillance system. This paper reports a retrospective survey of STD clinics in Italy, intended to form an epidemiological base for further development of STD surveillance. The data for 1986-87 and 1988 on a predefined set of diseases, all of them sexually transmitted, were collected from 85 of 127 centres contacted. The data obtained offer the first national figures for some STD not included in the statutory notification list, such as chlamydial infection, herpes and genital warts, as well as HIV infections. Those data show an increase in time frequencies. For gonorrhoea and syphilis, it was possible to compare our data with statutory notifications, showing a large gap between notified and reported cases. This gap is not stable in time (increasing in time) or in geographical area (increasing from north to south).
\end{abstract}

\section{Introduction}

The relevance of STD in public health has increased dramatically in recent years. This change has been a consequence of a number of factors which include: modifications in the pattern of this group of diseases, awareness of the worrying sequelae of some STD (infertility, perinatal mortality, infant morbidity and cancer),${ }^{12}$ and the recent correlation found between STD and HIV infection..$^{3-7}$ As a result, an increasing need for reliable data, both for effective epidemiological surveillance and for prevention strategies, has emerged. ${ }^{89}$

The Italian compulsory notifiable infectious dis-

Operational Centre for AIDS, National Institute of Health, Rome, Italy

D Greco, M Giuliani, B Suligoi, M Panatta, A Giannetti*

*Member Dermatologist of the National AIDS Committee (CNA). eases list, published by the National Institute of Statistics (Istituto Nazionale di Statistica, ISTAT) includes four STD, the rates of which should be representative of the national STD situation for both geographical distribution and temporary trends. However, the four notified pathologies (syphilis, gonorrhoea, lymphogranuloma venereum and chancroid) are inadequate for monitoring STD. Some of them have almost completely disappeared, while other diseases which are progressively expanding (Chlamydia trachomatis infections, herpes genitalis, genital warts, non gonococcal genital infections, etc) are not even considered in this list. Moreover, there seems to be considerable under-reporting in the Italian rates for syphilis and gonorrhoea in comparison with other European countries (5 to 50 times lower, respectively, for 1987$)^{10}$ and with the United States (10 to 150 times lower, respectively, for the same year). ${ }^{11}$

The considerations described above prompted us to take a national survey of STD clinics to verify whether data reported were qualitatively and quantitatively representative of the Italian STD situation. This study concerns the analysis of data obtained about such STD and their comparison with statutory notifications.

\section{Methods}

The list of STD centres, updated to 1988, was provided by the National Dermovenereological Association. In June 1989, a questionnaire was sent to the director of each centre; a second mailing was sent to those who did not answer after three months from the first mailing. The "non-responder" centres were subsequently all contacted by telephone.

The questionnaire investigates the organisation of the centre and the number of new diagnoses seen yearly in the previous three years $(86-88)$ for six diseases, with the following case definitions:

Confirmed gonorrhoea infections of all sites;

Primary and secondary syphilis;

Symptomatic, confirmed chlamydial infections; Confirmed HIV seropositivity;

First clinical episode confirmed herpes genitalis infections;

Human papilloma virus infections, including clinically confirmed cases. 
Table 1 New cases in 85 Italian STD clinics (Frequencies)

\begin{tabular}{|c|c|c|c|c|c|c|c|c|c|}
\hline & Gono & Syph & Chlamy & $H I V$ & $H S V 2$ & Condi & $V$ is $M$ & $V i s F$ & Vis total \\
\hline \multicolumn{10}{|l|}{ North } \\
\hline $\begin{array}{l}1986 \\
1987 \\
1988\end{array}$ & $\begin{array}{l}825 \\
561 \\
467\end{array}$ & $\begin{array}{l}2051 \\
1837 \\
1464\end{array}$ & $\begin{array}{l}802 \\
913 \\
916\end{array}$ & $\begin{array}{r}636 \\
1164 \\
1658\end{array}$ & $\begin{array}{l}422 \\
486 \\
698\end{array}$ & $\begin{array}{l}3367 \\
3548 \\
4545\end{array}$ & $\begin{array}{l}33160 \\
38024 \\
39455\end{array}$ & $\begin{array}{l}18098 \\
19057 \\
19387\end{array}$ & $\begin{array}{l}51258 \\
57081 \\
58842\end{array}$ \\
\hline $\begin{array}{l}\text { Central } \\
1986 \\
1987 \\
1988\end{array}$ & $\begin{array}{l}407 \\
257 \\
209\end{array}$ & $\begin{array}{l}493 \\
347 \\
437\end{array}$ & $\begin{array}{l}393 \\
586 \\
415\end{array}$ & $\begin{array}{l}149 \\
130 \\
162\end{array}$ & $\begin{array}{l}238 \\
253 \\
172\end{array}$ & $\begin{array}{l}841 \\
921 \\
916\end{array}$ & $\begin{array}{l}11023 \\
10405 \\
11296\end{array}$ & $\begin{array}{l}4166 \\
4548 \\
7016\end{array}$ & $\begin{array}{l}15189 \\
14953 \\
18312\end{array}$ \\
\hline $\begin{array}{l}\text { South } \\
1986 \\
1987 \\
1988\end{array}$ & $\begin{array}{l}315 \\
310 \\
315\end{array}$ & $\begin{array}{l}424 \\
416 \\
449\end{array}$ & $\begin{array}{l}470 \\
495 \\
512\end{array}$ & $\begin{array}{r}36 \\
128 \\
112\end{array}$ & $\begin{array}{l}328 \\
357 \\
382\end{array}$ & $\begin{array}{l}1180 \\
1189 \\
1362\end{array}$ & $\begin{array}{l}11741 \\
12714 \\
14982\end{array}$ & $\begin{array}{l}5696 \\
6278 \\
8205\end{array}$ & $\begin{array}{l}17437 \\
18992 \\
23187\end{array}$ \\
\hline $\begin{array}{l}\text { Italy } \\
1986 \\
1987 \\
1988\end{array}$ & $\begin{array}{r}1547 \\
1128 \\
991\end{array}$ & $\begin{array}{l}2968 \\
2600 \\
2350\end{array}$ & $\begin{array}{l}1665 \\
1904 \\
1843\end{array}$ & $\begin{array}{r}820 \\
1427 \\
2052\end{array}$ & $\begin{array}{r}988 \\
1096 \\
1252\end{array}$ & $\begin{array}{l}5388 \\
5658 \\
6823\end{array}$ & $\begin{array}{l}55924 \\
61143 \\
65733\end{array}$ & $\begin{array}{l}27960 \\
29883 \\
34608\end{array}$ & $\begin{array}{r}83884 \\
91026 \\
100341\end{array}$ \\
\hline
\end{tabular}

The total number of visits performed each year was also registered. Each centre was asked to declare the routine laboratory methods used to confirm the above mentioned diseases.

Questionnaires were manually checked and put into a specifically programmed computer data-base: questionnaires from centres declaring themselves not active as STD clinics or reporting zero cases were not used.

Statutory notifications for gonorrhoea and syphilis were obtained from ISTAT ${ }^{12}$ : the notifications' case definitions are "gonorrhoea infections" and "syphilis with active contagious lesions", without further specifications.

\section{Results}

Out of the 127 centres contacted, 57 responded to the first questionnaire. The second mailing accounted for 44 more centres. There was a final response of 101

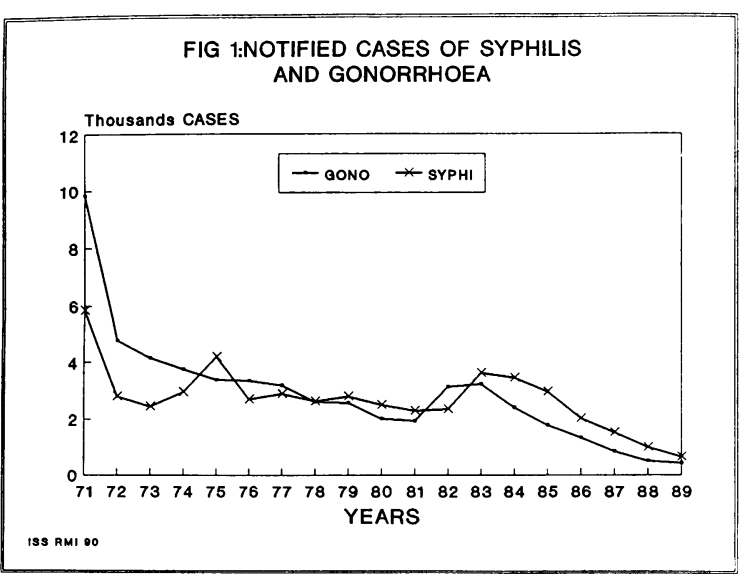

Figure 1 Trend of statutory notifications for gonorrhoea and syphilis in Italy (1971-1989). centres. Out of the 26 non-responder centres, 24 reported they were not STD clinics but only dermatological services and 2 were not identified. Of the 101 responding centres, 16 were no longer active STD clinics, so they were excluded from this analysis. Eighty five STD clinics remained as the basis for the present study.

The new cases collected, by year, for each disease in the 85 STD clinics are shown in table 1. A large geographical area aggregation has been performed. The last column includes the total number of visits performed in the centres: it is not the sum of reported cases.

A decreasing trend appears for gonorrhoea and syphilis, together with a stable or increasing trend for the other infections. The trend for gonorrhoea and syphilis is compatible with the trend of statutory notifications (fig 1 ).

Table 2 shows the comparison, by year and area, of statutory notifications versus clinical returns for syphilis and gonorrhoea, and the ratio of diagnoses to notifications.

Many of the cases included in the clinical returns are not present in the notifications: overall in 1988 the clinical returns have $90 \%$ more cases of gonorrhoea and $131 \%$ more of syphilis than statutory notifications. This gap is different by geographical area and increases in time. As can be seen in table 2, the ratio for gonorrhoea goes from 1.17 in 1986 to 1.95 in 1988, and for syphilis the ratio is 1.46 in 1986 and 2.36 in 1988. Figure 2 shows the ratios of gonorrhoea and syphilis for 1988 .

\section{Discussion}

The tendency to gloss over STD has met the growing demand for behavioural freedom of choice; however, this freedom has been misinterpreted, leading to a disregard of the seriousness of STD. The spread of HIV infection has once again focused the attention of 
Table 2 New cases in Italian STD clinics compared with notifications by geographic area frequencies and ratios diagnoses/ notifications

\begin{tabular}{|c|c|c|c|c|c|c|c|}
\hline & \multirow[b]{2}{*}{ Year } & \multicolumn{3}{|c|}{ Gono ratio } & \multicolumn{3}{|c|}{ Syphi ratio } \\
\hline & & Not & Dia & $D / N$ & Not & Dia & $D / N$ \\
\hline North & $\begin{array}{l}1986 \\
1987 \\
1988\end{array}$ & $\begin{array}{l}836 \\
566 \\
355\end{array}$ & $\begin{array}{l}825 \\
561 \\
467\end{array}$ & $\begin{array}{l}0.99 \\
0.99 \\
1.32\end{array}$ & $\begin{array}{r}1351 \\
894 \\
555\end{array}$ & $\begin{array}{l}2051 \\
1837 \\
1464\end{array}$ & $\begin{array}{l}1.52 \\
2.05 \\
2.64\end{array}$ \\
\hline Central & $\begin{array}{l}1986 \\
1987 \\
1988\end{array}$ & $\begin{array}{l}360 \\
199 \\
132\end{array}$ & $\begin{array}{l}407 \\
257 \\
209\end{array}$ & $\begin{array}{l}1.13 \\
1.29 \\
1.58\end{array}$ & $\begin{array}{l}532 \\
486 \\
346\end{array}$ & $\begin{array}{l}493 \\
347 \\
437\end{array}$ & $\begin{array}{l}0.93 \\
0.71 \\
1.26\end{array}$ \\
\hline South & $\begin{array}{l}1986 \\
1987 \\
1988\end{array}$ & $\begin{array}{r}126 \\
73 \\
22\end{array}$ & $\begin{array}{l}315 \\
310 \\
315\end{array}$ & $\begin{array}{r}2 \cdot 50 \\
4 \cdot 25 \\
14 \cdot 32\end{array}$ & $\begin{array}{r}146 \\
137 \\
94\end{array}$ & $\begin{array}{l}424 \\
416 \\
449\end{array}$ & $\begin{array}{l}2.90 \\
3.04 \\
4 \cdot 78\end{array}$ \\
\hline Total Italy & $\begin{array}{l}1986 \\
1987 \\
1988\end{array}$ & $\begin{array}{r}1322 \\
838 \\
509\end{array}$ & $\begin{array}{r}1547 \\
1128 \\
991\end{array}$ & $\begin{array}{l}1.17 \\
1.35 \\
1.95\end{array}$ & $\begin{array}{r}2029 \\
1517 \\
995\end{array}$ & $\begin{array}{l}2968 \\
2600 \\
2350\end{array}$ & $\begin{array}{l}1.46 \\
1.71 \\
2.36\end{array}$ \\
\hline
\end{tabular}

health care authorities on STD and has made financial resources available for STD surveillance. Moreover, the identification of the STD clinics' patients as one of the most appropriate sentinel groups for monitoring HIV trend has led to the establishment of a specific STD surveillance network in Italy, which has been modelled on those of other European countries.

This study offers for the first time national figures for chlamydial infections, herpes infections and genital warts. For syphilis and gonorrhoea, the comparison between the statutory notifications and our data shows an important gap: for each case of notified syphilis there are 2.3 unnotified; similarly, for each case of gonorrhoea notified there are two cases unnotified. This gap is not stable in time or geographical area: the proportion of cases not notified increases in-time and follows a north-south trend, reaching astonishing peaks in Southern Italy, where the results show 14 cases of unnotified gonorrhoea for each notified case.

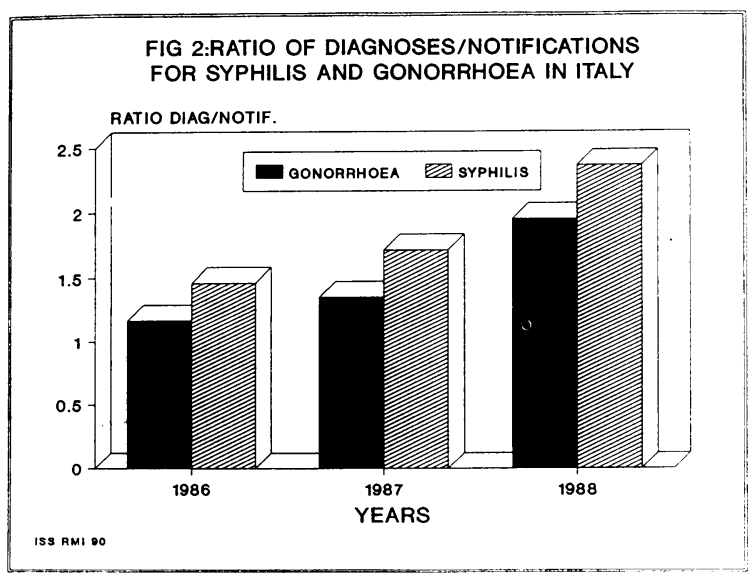

Figure 2 Ratio of clinical returns and statutory notifications for gonorrhoea and syphilis in 1988 in Italy.
It must be emphasised that public centres are more likely to report infectious diseases. Nevertheless, ISTAT data are underestimated if compared with data provided by the STD centres (all of them public), suggesting that patients seen by private physicians or other private clinical settings are not included in the mandatory notifications. This indicates that the magnitude of undernotification exceeds the gap seen in the present study. Furthermore, figures collected by the 85 STD centres are only a part of the real STD picture in Italy. This is confirmed, at least for gonorrhoea, by a study on spectinomicin prescriptions dispensed in Rome, in the Lazio Region, during 1985-87 (personal communication: Marina Maggini, 1989): the number of subjects who had a spectinomicin prescription by a general physician in Rome is 5.4 times greater than notifications reported for the whole Lazio Region (ISTAT) in those three years.

Our data show that the very relevant notification decrease for syphilis and gonorrhoea does not reflect the true situation. We found only a $36 \%$ and $21 \%$ decrease in gonorrhoea and syphilis, respectively, between 1986 and 1988, compared with the $61 \%$ and $51 \%$ decrease shown in the statutory notifications. It may well be that the arrival of the HIV infected population, with the extensive follow-up of paper work and bureaucracy for those patients, has reduced the attention given to classical STD notification.

As a result of this study, a routine surveillance network based on clinical returns is now operational in 36 large STD clinics in Italy. Moreover, the government has noted the STD problem and has proposed a law aimed at STD control. This is a good starting point for finding and enhancing adequate means for surveillance in an area that is of paramount importance in improving individual life.

Address for correspondence: Dr Donato Greco, Centro Operativo AIDS, Itstituto Superiore di Sanità, Viale Regina Elena 299, 00161 Roma, Italy. 
We thank the following centres for their kind collaboration: Alessandria: L Aulisa, S Sartoris; Ancona: A Morresi; Aosta: M Norat; Arezzo: A Scalese; Bari: G Angelini; Belluno: G Marson; Bergamo: T Cainelli; Bologna: M Negosanti, G P Carboni; Bolzano: E Vigl; Brescia: S Graifemberghi; Brindisi: E Sbano; Cagliari: P Biggio, U Lostia; Caserta: P Battarra; Catania: S Randazzo, A Sapuppo, C Lazzaro; Catanzaro: V Marincola Cattaneo; Chieti: P Amerio; Como: C Pelfini; Cosenza: S Gargano; Cremona: G Lazzari; Ferrara: A Califano; Firenze: G Zuccati; Foggia: L Altobella, $M$ Lomuto; Forli: G Landi, A Piredda; Genova: L Massone, G Piccardo, G Farris, A Rebora; Gorizia: M Lo Brutto; L'Aquila: V Giuliani; La Spezia: G Rossi, M Gigantesco; Lecco: D Fideli; Lucca: S Ghittoni; Macerata: R Bianchini; Mantova: L Stevanin; Massa: G Vezzoni; Messina: F Gallina, B Guarneri; Milano: G Galbiati, E Alessi, A Finzi; Modena: M Coppini; Napoli: P Donofrio, O Bianchi, M Pisani, M Avellino; Novara: G Leigheb; Padova: C Rabito; Palermo: M Arico'; Parma: A Alinovi; Pavia: G Rabbiosi; Perugia: P Lisi, P Calandra; Pesaro: F Carbone; Pisa: E Mian; Pordenone: R Guerra; Ravenna: A Rafanelli, F Pasi; Roma:D Cerimele, G Gentili; Rovigo: D Lorusso; Sassari: P Fabbri; Savona: L Bruni, D Dellavalle; Sienna: L Andreassi; Taranto: F Sannicandro; Teramo: A Franchi; Torino: G Zina; Trento: M Cristofolini; Treviso: D Simonetto; Trieste: C Scarpa, E Zar; Varese: A Pazzaglia; Venezia: R Bassi; Vercelli: L Vittone, E Colombo; Verona: $\mathrm{G}$ Chieregato.

1 Alessi E. Le infezioni da contagio sessuale. Federazione Medica 1988;XLI:409-17.

2 Meheus A. Sexually transmitted pathogens in mother and newborn. Ann NY Acad Sci 1988;549:203-14.
3 Quinn TC, Glasser D, Cannon RO, et al. Human immunodeficiency virus infection among patients attending clinics for sexually transmitted diseases. N Engl J Med 1988;318: 197-203.

4 Weekly Epidemiological Record: Acquired immunodeficiency syndrome and sexually transmitted diseases. Geneva: WHO, 1989, 6445-52.

5 Pepin J, Plummer FA, Brunham RC, Piot P, Cameron DN, Ronald AR. The interaction of HIV infection and other sexually transmitted diseases: an opportunity for intervention. AIDS 1989;3:3-9.

6 Piot $P$, Laga $M$. Genital ulcers, other sexually transmitted diseases: an opportunity for intervention. $\mathrm{Br} M e d J 1989$; 298:623-4.

7 Hearts N, Hulley SB. Preventing the heterosexual spread of AIDS. JAMA 1988;259:2428-32.

8 Morton RS. Control of sexually transmitted diseases today and tomorrow. Genitourin Med 1987;63:202-9.

9 WHO "Control of sexually transmitted diseases." 1985:25-32. Report of a WHO scientific working group: Washington, April 1982. MacMillan-Spottiswoode, UK

10 WHO Technical Report Series, No 736, 27. (Comitè OMS d'experts des maladies vénériennes et des tréponématoses. Sixième rapport). Geneva: Schuler SA, 1986.

11 Center for Diseases Control. "Syphilis and congenital syphilisUnited States 1959-1988." MMWR, 1988;37:486-9.

12 In: "Annuario ISTAT delle malattie infettive." Rome: ISTAT, 1986, 1987, 1988.

Accepted for publication 2 July 1990 